\title{
Steatocystoma multiplex - case report
}

\author{
Anca E Chiriac ${ }^{* 1}$, Tudor Pinteala ${ }^{1}$, Piotr Brzezinski ${ }^{2}$ \\ 1 "Grigore T. Popa" University of Medicine and Pharmacy, lasi, Romania, ${ }^{2}$ Department of \\ Dermatology, 6th Military Support Unit, Ustka, Poland
}

\begin{abstract}
\section{Case report}

A 28 year-old Caucasian male patient was seen in the Dermatology Unit for multiple nodular lesions, localized on the scrotum, observed by the patient a few months prior to consultation (Fig. 1).
\end{abstract}

Steatocystoma multiplex is a rare, benign, sporadic or familial disorder (autosomal dominant mutation in Keratin 17). Diagnosis is based on clinical grounds: multiple cysts, localized in axilla, groin, neck, scrotum and proximal extremities. We describe a case of Steatocystoma multiplex in a 28 year old male patient with a family history of similar lesions.

Keywords: Steatocystoma multiplex, familial disorder, scrotum

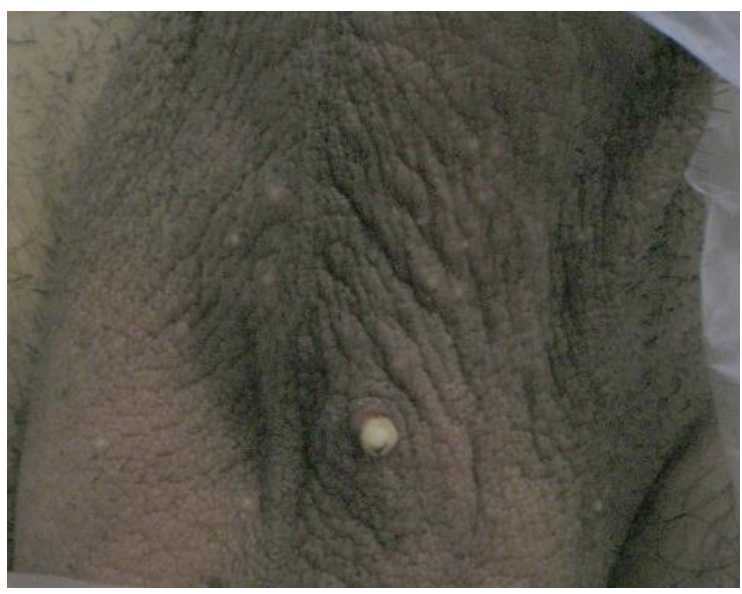

Fig. 1. Round cysts of different size, on the scrotum

Received: March 2014; Accepted after review: April 2014; Published: June 2014

${ }^{*}$ Corresponding author: Anca E. Chiriac, "Grigore T. Popa" University of Medicine and Pharmacy lasi, Romania. Email: chiriancut@yahoo.com.
On clinical examination numerous, whitish and of different size (ranging from a few $\mathrm{mm}$ to $3 \mathrm{~cm}$ ) cystic tumors were detected on the scrotum, not accompanied by any symptoms. The patient was in good health status, he denied any past personal medical history and drug intake, but he admitted that similar lesions were reported by his father. Based on simple clinical observation, a diagnosis of Steatocystoma multiplex was made, the patient refused skin biopsy. The patient was reassured by the benignity of his disease, different therapeutical options have been proposed and genetic counseling was advised.

\section{Discussions}

Steatocystoma multiplex is also known as epidermal polycystic disease and sporadic or familial disorder (autosomal dominant mutation in keratin 17) [1].

Usually lesions appear during adolescence or around twenties (maybe a hormonal trigger), but are fully expressed and diagnosed in adulthood or even later. No gender prevalevance has been reported.

Diagnosis is mostly clinical: multiple dermal cysts, of different size, involving areas with high density of sebaceous units: axilla, groin, 
neck, scrotum and proximal extremities; but rare forms have described the lesions on the face [2], generalized [3], scalp [4].

A classification can be made: localized, generalized; facial, acral, and the suppurative types; solitary lesions are known as Steatocystoma simplex [4].

Steatocystoma multiplex can be associated with pachyonychia congenita type 2 (which is characterized by hypertrophic nail dystrophy, focal keratoderma, multiple pilosebaceous cysts, and myriad conditions associated with ectodermal dysplasia) or eruptive vellus hair cysts $[1,5]$.

The diagnosis is confirmed by histopathological report (Table 1).

Treatment options are: cryotherapy, carbon dioxide laser, surgical excision, oral tretinoin or simple surveillance.

Particularities of the present case: a familial case of Steatocystoma multiplex in a 28 yearold male patient with localized lesions on the scrotum.

Table 1. Differential diagnosis based on histopathological findings.

\begin{tabular}{ll}
\hline Eruptive Vellus Hair Cysts & $\begin{array}{l}\text { Dermal cysts lined by stratified squamous epithelium, } \\
\text { with granular layer, contained vellus hairs; no } \\
\text { sebaceous glands [6] }\end{array}$ \\
\hline Epidermoid cysts & $\begin{array}{l}\text { Cysts lined by stratified epithelium, with granular layer, } \\
\text { lamellar keratin inside [7] }\end{array}$ \\
Milia & $\begin{array}{l}\text { Small cysts in the superficial dermis coated by } \\
\text { epithelium with granular cell layer' contains lamellar } \\
\text { keratin [7] }\end{array}$ \\
Trichilemmal cysts & $\begin{array}{l}\text { Cysts lined by squamous epithelium without granular } \\
\text { layer, filled with homogenous keratin [7] }\end{array}$ \\
Steatocystomas & $\begin{array}{l}\text { Cysts lined by stratified squamous epithelium without } \\
\text { granular layer and vellus hairs inside the cavity; } \\
\text { sebaceous lobules close to the cystic wall [7] }\end{array}$
\end{tabular}

\section{References}

1. Covello SP, Smith FJ, Sillevis Smitt JH et al: Keratin 17 mutations cause either steatocystoma multiplex or pachyonychia congenita type 2. $\mathrm{Br} J$ Dermatol, 1998, 139 (3):475-80.

2. Riedel C, Brinkmeier T, Kutzne H, Plewig G, Frosch PJ: Late onset of a facial variant of steatocystoma multiplex-calretinin as a specific marker of the follicular companion cell layer. $J$ Dtsch Dermatol Ges, 2008, 6(6):480-2.

3. Kamra HT, Gadgil PA, Ovhal AG, Narkhede RR: Steatocystoma multiplex-a rare genetic disorder: a case report and review of the literature. J Clin Diagn Res, 2013, 7(1):166-8.
4. Kim SJ, Park HJ, Oh ST, Lee JY, Cho BK. A case of steatocystoma multiplex limited to scalp. Ann Dermatol, 2009; 21(1):106-09.

5. Yanagi T, Matsumura T: Steatocystoma multiplex presenting as acral subcutaneous nodules. Acta Derm Venereol, 2006, 86(4):374-5.

6. Park KY, Oh KK, Noh TW: Steatocystoma multiplex: Mammographic and sonographic manifestations. AJR, 2003, 180:27.

7. Kamra HT, Gadgil PA, Ovhal AG, Narkhede RR.: Steatocystoma multiplex-a rare genetic disorder: a case report and review of the literature. J Clin Diagn Res, 2013, 7(1):166-8. 